\title{
Seminário Atualidade de Sérgio Buarque de Holanda
}

Dando início às comemorações do cinquentenário do IEB, que ocorre no ano de 2012, o Instituto realizou no final do ano passado um importante seminário em torno a um dos seus fundadores: Sérgio Buarque de Holanda. Para tanto, foram convidados especialistas diversos, que promoveram discussões interdisciplinares sobre a obra do autor e seu legado para a atualidade.

$\mathrm{O}$ evento contou com público numeroso e teve a seguinte programação:

Seminário Atualidade de Sérgio Buarque de Holanda (setembro de 2011)

13/9 (15 h):

14/9 Cultura e Colônia (9 h):

14/9 Império e Política (14 h):

15/9 Modernismo (9 h):

15/9 Cordialidade e Contemporaneidade (14 h):

16/9 Território e Cidades (9h):

16/9 Democracia e Cultura popular (14 h):
Mesa de abertura

Conferência: Antonio Candido

Inauguração da exposição Atualidade de Sérgio Buarque de Holanda

Luiz Armando Bagolin

Laura de Mello e Souza

Mônica Duarte Dantas

Maria Odila Leite da Silva Dias

Richard Graham

Marcos Antônio de Moraes

Pedro Meira Monteiro

Antônio Arnoni Prado

Walter Garcia

João Cezar de Castro Rocha

Heloísa Maria Murgel Starling

Vanderli Custódio

Nestor Goulart Reis Filho

Antônio Carlos Robert de Moraes

Alexandre de Freitas Barbosa

Brasílio Sallum Jr.

Maria Alice Rezende de Carvalho 